\title{
PENGGUNAAN PENDEKATAN KUIS TIM UNTUK MENINGKATKAN TANGGUNG JAWAB INDIVIDU DALAM KELOMPOK BELAJAR PADA SISWA KELAS 8A \\ SMP N 1 SUKOMORO KABUPATEN MAGETAN \\ TAHUN PELAJARAN 2013/2014
}

\author{
Siwignyo*
}

\begin{abstract}
Abstrak
Dengembangan diri melalui pembelajaran aktif dengan penggunaan pendekatan Kuis tim ini lebih memusatkan pada keragaman kegiatan siswa dalam kelompok belajar yang dinamis, mulai dari pemahaman konsep materi pembelajaran, membuat pertanyaan merancang kegiatan kelompok, pembagian tugas anggota kelompok, merencanakan presentasi sampai pada pemberian penghargaan berupa score dan penobatan kelompok terbaik pada setiap sesi. Oleh sebab itu, penggunaan model pembelajaran aktif dengan pendekatan kuis tim ini diharapkan dapat mengatasi masalah masalah pengembangan diri ,utamanya masalah tanggung jawab siswa dalam hubungannya dengan kelompok belajarnya. Penelitian ini bertujuan untuk meningkatkan tanggung jawab individu dalam penyelesaian tugas - tugas belajarnya secara kelompok, dalam rangka proses pengembangan diri.

Subyek penelitian ini adalah siswa kelas 8A SMP Negeri 1 Sukomoro Magetan Tahun Pelajaran 2013/2014. Penelitian Tindakan Kelas ini dirancang dalam 2 Siklus, masing-masing siklus terdiri atas tahap perencanaan, pelaksanaan, observasi, dan refleksi. Rencana tindakan beserta instrumen penelitian ( SAP, bahan ajar,lembar observasi,dan angket ) disiapkan oleh peneliti. Dalam pelaksanaan tindakan di kelas peneliti bertindak sebagai guru pembimbing sekaligus pengamat. Hasil tindakan dalam suatu siklus yang berupa keaktifan siswa, serta kemajuan - kemajuan aspek kepribadian dan pengembangan diri siswa, dievaluasi sebagai bahan pertimbangan dalam merencanakan tindakan dalam siklus berikutnya. Materi yang digunakan sebagai obyek penelitian adalah model pembelajaran aktif kuis tim dan implementasinya.

Hasil penelitian menunjukkan bahwa penerapan model pembelajaran aktif dengan pendekatan Kuis Tim dapat meningkatkan tanggung jawab individu dalam kelompok belajar. Peningkatan tanggungjawab tersebut dapat diketahui dari makin aktifnya siswa dalam menyelesaikan tugas-tugas dalam kelompok, menjawab pertanyaan-pertanyaan yang muncul dalam presentasi kelompok, semangat bersaing secara sehat dalam kelompok dan membangun kekompakan kelompok. Model pembelajaran melalui pendekatan ini mendapat respon positif dari seluruh siswa dengan idikator hasil analisa angket pada akhir sesi, dan meningkatnya penyelesaian tugas-tugas dan unjuk kerja.
\end{abstract}

Kata-kata Kunci : Model pembelajaran kuis tim, tanggung jawab individu, kelompok belajar.

* Guru PPKn SMK Bendo 


\section{PENDAHULUAN}

Persoalan-persoalan

pembelajaran yang muncul di sekolah sangat beragam. Mulai dari penggunaan strategi pembelajaran, metode, materi, sumber daya manusianya sampai pada sarana dan prasarana pembelajaran, keadaan semacam ini perlu disikapi secara sinergis oleh pelaku pembelajar antara lain: guru, siswa, manager sekolah dan lain-lainnya.

Persoalan yang sangat menonjol dan perlu tindakan dengan segera dan berkelanjutan adalah tanggung jawab siswa dalam menyelesaikan tugas-tugas akademisnya. Berdasarkan keluhan beberapa guru bidang studi, keluhan guru-guru pembimbing, dan para instansi yang terkait dengan praktek kerja industri, khususnya yang sangat berkaitan dengan target penyelesaian tugas-tugas kelompok siswa. Menjelang penyelesaian tugas akhir project work siswa dituntut memiliki komitmen kerja dan tanggung jawab yang tinggi dalam mengemban tugas tersebut. Akhir-akhir ini sangat dirasakan bahwa adanya kecenderungan menurunnya aspekaspek dan nilai-nilai tanggungjawab siswa terhadap tugas belajarnya. Keadaan ini memerlukan upaya dari para guru bidang studi maupun guru pembimbing untuk segera mengambil tindakan edukatif, baik yang berupa kegiatan instruksional maupun kegiatan bimbingan diluar pembelajaran. Untuk mewujudkan upaya tersebut dipilihlah penggunaan metode pembelajaran aktif kuis tim sebagai alternatif dalam usaha memecahkan masalah tersebut.

Metode kuis tim merupakan salah satu bentuk dari pembelajaran aktif yang dikembangkan melalui pemberdayaan kelompok. Mengefektifkan kerjasama, dan membangun rasa percaya diri individu, serta membangun dan meningkatkan tanggungjawab individu itu dalam kelompok tersebut.

Aspek pengembangan diri siswa antara lain adalah tanggung jawab, disiplin, kepemimpinan, percaya diri, kemandirian, keberanian mengambil keputusan, motivasi berprestasi, bekerjasama, kejujuran, bersaing secara sehat, sanggup berbeda dengan yang lain, mengambil inisiatif dan sebagainya. 
Untuk bidang pengembangan diri, pengembangan kepribadian dan aspek emosi, memerlukan strategi dan teknik tertentu, melalui pembelajaran, pembiasaan dan latihan-latihan.

Guru dan siswa memiliki hubungan yang sinergis dalam suasana yang lebih menyenangkan dan membutuhkan komunikasi yang hangat dengan menumbuhkan kepercayaan satu sama lain secara terus menerus, sehingga dapat mewujudkan suasana kondusif yang lebih tepatnya disebut bimbingan.

$\begin{array}{ccc}\text { Bimbingan } & \text { dalam } & \text { skop } \\ \text { pengembangan } & \text { diri } & \text { yang }\end{array}$
disampaikan melalui pembelajaran aktif klasikal, akan lebih efektif jika menggunakan strategi atau pendekatan yang tepat. Pendekatan yang sering digunakan oleh para guru pembimbing dan dianggap efektif adalah pendekatan kelompok, disebut juga bimbingan kelompok, kelompok dimaksud adalah kelompok belajar.

Jereme Bruner membahas sisi sosial proses belajar dalam buku klasiknya, Toward a Theory of instruction. Dia menjelaskan tentang "kebutuhan mendalam manusia untuk merespon orang lain dan untuk bekerjasama dengan mereka guna mencapai tujuan, "yang mana hal ini dia sebut resiprositas (hubungan timbal-balik). Bruner berpendapat bahwa resiprositas merupakan sumber motivasi yang bisa dimanfaatkan oleh guru untuk menstimulasi kegiatan belajar. Dia menulis sebagai berikut: "Di mana dibutuhkan tindakan bersama, dan di mana resiprositas diperlukan bagi kelompok untuk mencapai suatu tujuan,di situlah terdapat proses yang membawa individu ke dalam pembelajaran, membimbingnya untuk mendapatkan kemampuan yang diperlukan dalam pembentukan kelompok"(Bruner :1966).

\section{Konsep-konsepnya Maslow} dan Bruner melandasi perkembangan metode belajar kolaboratif yang sedemikian populer dalam lingkup pendidikan masa kini. Menempatkan siswa dalam kelompok dan memberi mereka tugas yang menuntut mereka untuk bergantung satu sama lain dalam mengerjakannya merupakan cara yang bagus untuk memanfaatkan kebutuhan sosial siswa. Mereka menjadi cenderung lebih terlibat dalam kegiatan belajar 
karena mereka mengerjakannya bersama teman-teman. Begitu terlibat, mereka juga langsung memiliki kebutuhan untuk membicarakan apa yang mereka alami bersama teman yang mengarah kepada hubungan-hubungan lebih lanjut.

Kegiatan belajar bersama dapat membantu memacu belajar aktif. Kegiatan belajar dan mengajar di kelas memang dapat menstimulasi belajar aktif, namun kemampuan untuk mengajar melalui kegiatan kerjasama kelompok-kecil akan memungkinkan untuk menggalakkan kegiatan belajar aktif dengan cara khusus. Apa yang didiskusikan siswa dengan teman-temannya dan apa yang diajarkan siswa kepada temantemannya memungkinkan mereka untuk memperoleh pemahaman dan penguasaan materi pelajaran. Metode kelompok belajar bersama yang terbaik, pemberian tugas yang berbeda kepada siswa akan mendorong mereka untuk tidak hanya belajar bersama namun juga mengajarkan satu sama lain dan mereka merasa satu tim.

Hasil pengamatan yang telah dihimpun menunjukkan adanya kecenderungan bahwa, (1) sebagian siswa cerdas belum bisa mencapai prestasi yang diharapkan, sebagian siswa belum menyadari tanggung jawabnya dalam penyelesaian tugas secara individu maupun kelompok, (3) Sebagian siswa belum paham bagaimana bekerja secara tim, (4) kurangnya pemahaman diri masing-masing siswa dalam penyelesaian tugas kelompok, (5) masih adanya siswa yang terlalu bergantung dengan teman, (6) sebagian siswa belajar kurang bersungguh-sungguh,asalasalan,terpaksa dsb.

Dalam rangka pengembangan diri siswa melalui pembelajaran aktif kuis tim dipandang sebagai metode atau pendekatan paling tepat untuk meningkatkan tanggung jawab individu dalam kelompok belajar. Pada pembelajaran aktif Kuis Tim, siswa bekerja bersama-sama untuk mencapai tujuan khusus yaitu menyelesaikan sebuah tugas. Hal itu dapat dicapai dengan cara : Pertama 4 , Mengajak siswa bekerja bersamasama untuk menyelesaikan tugastugas, membahas masalah dalam diskusi, dan menyelesaikan tugas kelompok lainnya. Kedua, 
pengaturan siswa dalam kelompok kecil yang heterogen menantang dan memotivasi siswa untuk saling membantu, berbagi tugas dan mendukung belajar teman lainnya dalam kelompok. Ketiga, penumbuhan rasa tanggung jawab untuk belajar dan bekerja sama dalam upaya bersaing antar kelompok. Keempat, terjadinya proses membangun tim atau kelompok yang kuat dalam belajar.

Dengan memperhatikan beberapa keuntungan metode atau pendekatan kuis tim, peneliti menganggap penting untuk menerapkan pendekatan ini sebagai salah satu sumbangan menciptakan Pembelajaran Aktif, Kreatif, Efektif dan Menyenangkan (PAKEM) dalam rangka pengembangan diri siswa.

\section{METODE PENELITIAN}

\section{Setting Penelitian}

$\begin{array}{clr}\text { Penelitian } & \text { ini } & \text { adalah } \\ \text { penelitian tindakan } & \text { kelas, } & \text { model }\end{array}$ Stephen Kemmis dan Mc. Taggart (1998) mengadopsi dari Suranto, 2000; 49, model ini menggunakan sistem spiral refleksi diri yang dimulai dari rencana, tindakan, pengamatan, refleksi dan perencanaan kembali yang merupakan dasar untuk suatu ancang-ancang pemecahan masalah. Seperti yang diungkapkan oleh Mills GE 200;17, "Stephen Kemmis has created a well known representation of the action research spiral ...". Peneliti menggunakan model ini karena dianggap paling praktis dan aktual.

Penelitian tindakan kelas ini dilaksanakan di SMP Negeri 1 Sukomoro Magetan kelas 8A. Perangkat pembelajaran yang dikembangkan meliputi : Skenario pembelajaran, Lembar Kegiatan Siswa, lembar pengamatan guru dan satuan layanan yang diambil dari silabus.

Skenario pembelajaran dibuat sebagai panduan guru agar pelaksanaan pembelajaran sesuai dengan yang direncanakan. Lembar Kegiatan Siswa digunakan membuat daftar pertanyaan. Tugas Dari Guru/Kuis Lembar Pengamatan/Observasi guru digunakan untuk mengetahui perkembangan kegiatan/ perubahan tingkah laku siswa. Menurut Waseno (1994 : 17) Proses penelitian tindakan ini merupakan proses daur 
ulang mulai dari tahap perencanaan.

Tindakan pengamatan (observasi)

dan refleksi (perenungan-pemikiran evaluatif), berulang sesuai banyaknya siklus.

\section{Rancangan Penelitian}

Penelitian tindakan kelas ini direncanakan dalam 2siklus , masing-masing siklus terdiri dari : penyusunan rencana tindakan ,pelaksanaan tindakan ,melakukan obsevasi, pembuatan analisis dan refleksi serta membuat rencana peningkatan(improvement plan) tindakan berikutnya:

\section{SIKLUS I}

a. Rencana tindakan 1:

Mengidentifikasi

permasalahan, merencanakan penelitian secara keseluruhan, menyusun desain pembelajaran dan strateginya, menyusun perangkat pembalajaran, menyiapkan bahan ajar, menyiapkan alat/menyusun alat perekam data, menyusun rencana pengolahan data.

b. Pelaksanaan tindakan I dan pengamatan

$\begin{array}{ccr}\text { Pada } & \text { tahap } & \text { ini } \\ \text { dilaksanakan } & \text { tindakan } & \text { yang }\end{array}$

telah direncanakan sebagai berikut : melakukan pembelajaran sesuai skenario (persiapan, penyampaian, pelatihan dan penampilan hasil), siswa melakukan kegiatan sesuai langkah-langkah yang terjadi, mengamati kegiatan siswa secara komprehensif dengan memanfaatkan alat perekam data yang sudah disiapkan.

c. Analisis dan Refleksi

Analisis dilakukan secara deskriptif terhadap data hasil pengamatan, kemudian sintesis, pemaknaan penjelasan, penyimpulan data dan informasi yang telah terkumpul. Hasil yang diperoleh berupa temuan tingkat efektifitas rancangan pembelajaran yang dibuat, dan daftar permasalahan yang muncul di lapangan, selanjutnya dipakai sebagi dasar untuk melakukan perencanaan ulang. Setiap aspek memiliki indikator, Indikator bertanggung jawab adalah : paham dan tanggung jawab terhadap tugas atau beban yang di emban, melaksanakan tugas dan konsultasi bila ada masalah dalam melaksanakan 
tugas, dan melaporkan hasil pelaksanaan tugas.

\section{SIKLUS II}

a. Rencana Tindakan 2

Kegiatan yang dilakukan pada tahap ini meliputi perencanaan kegiatan dengan menentukan alternatif pemecahan masalah untuk memperbaiki kekurangan pada siklus I.

b. Pelaksanaan tindakan 2 dan pengamatan

Rincian tindakan sama dengan tindakan 1 ditambah dengan tindakan lain sebagai pengembangan tindakan I

c. Analisis dan refleksi II

Analisis dilakukan dengan membandingkan hasil angket awal dengan hasil angket evaluasi dan lembar pengamatan. Apakah tindakan yang dilakukan dapat meningkatkan tanggung jawab individu. Hasil analisis dan refleksi dipergunakan untuk menentukan hasil akhir dari kegiatan pada siklus II.

\section{HASIL PENELITIAN}

\section{SIKLUS I}

\section{Pelaksanaan Tindakan.}

Pada pertemuan pertama siklus pertama membagi siswa menjadi delapan kelompok yang masing-masing beranggotakan 5 orang. Peneliti memaparkan judul materi pengembangan diri yang akan disajikan dalam pembelajaran kepada siswa dan sekaligus memperkenalkan metode pembelajaran aktif yang akan digunakan dalam menyajikan materi tersebut, yaitu metode kuis tim. Peneliti menjelaskan pada siswa pola pembelajaran tersebut. Adapun yang harus dilakukan oleh kelompok adalah membagi tugas anggota kelompok, berdiskusi membahas materi, membuat pertanyaan kuis dan sekaligus membuat skala penilaiannya. Merencanakan presentasi masing-masing kelompok dan menyiapkan refleksi tanggapan kelompok lain. Mengisi angket umpan balik.

Setelah terbentuk kelompok siswa diminta untuk duduk sesuai kelompoknya untuk membahas materi yang telah dipaparkan oleh peneliti secara kelompok siswa 
berdiskusi tentang materi, setiap anggota kelompok diharuskan membuat pertanyaan kuis dan sekaligus membuat jawabannya dan bertanggungjawab atas pengembangan pertanyaan atau jawaban soal kuis tersebut oleh kelompok lain.

\section{Kemudian kelompok}

menentukan skala skor atas jawaban kelompok lain dan memilih kelompok mana yang memperoleh skor tertinggi dalam presentasi itu dan berhak maju untuk presentasi berikutnya.

\section{Melakukan Obsevasi dan}

\section{Pencatatan data}

Pada pertemuan ke dua dilaksanakan presentasi dimulai dengan undian kelompok. Pada undian tersebut jatuh giliran untuk kelompok. Pada pertemuan kedua ini direncanakan ada 4 kelompok yang maju presentasi, masing-masing kelompok memiliki waktu 20 menit untuk presentasi, 10 menit terakhir digunakan untuk refleksi. Hasil presentasi pertama yaitu penampilan kelompok yang beranggotakan 5 orang menghasilkan lima pertanyaan yang dijadikan kuis, sedangkan pengumpulan skor berturut-turut sebagai berikut: Kelompok II mendapat skor 465, kelompok IV mendapat skor 315, kelompok VI mendapat skor 245, kelompok VII mendapat skor 140 dan kelompok VIII mendapat skor 90, sedangkan dua kelompok lainnya belum mendapatkan skor. Dengan dimikian pemenang pada sesson ini adalah kelompok II, kelompok tersebut berhak memimpin kuis pada sesson kedua. Demikian seterusnya sampai selesai penampilan presentasi 4 kelompok yang menghabiskan waktu 80 menit. Dari 4 kelompok yang presentasi tersebut ,secara keseluruhan yang mendapatkan skor tertinggi adalah kelompok II yaitu mendapat skor 465 .

$>$ Pembuatan Analisis dan Refleksi

Pada akhir sesson diadakan refleksi untuk melihat pengalaman secara individu maupun kelompok dalam perencanaan, pembuatan dan pelaksanaan kuis tahap pertama. Peneliti bertanya kepada para siswa: "Apa yang kalian rasakan selama bekerja secara kelompok dalam membuat kuis dan mempresentasikannya?" 
Dari pertanyaan itu ditemukan beberapa jawaban yang antara lain adalah: 11 siswa merasa kesulitan dalam mebuat pertanyaan dan jawabannya, 6 bingung, 4 siswa penasaran, 5 siswa kurang mengerti istilah dalam materi, 4 siswa merasa kesulitan menentukan scor jawaban, 8 siswa menyatakan waktunya terlalu sedikit, 3 siswa mengatakan kemampuan anggota kelompok tidak merata atau seimbang, yang lainnya tidak berpendapat. Pada kelompok yang yang belum aktif, peneliti memberi pertanyaan sebagai berikut:"Mengapa kalian belum mendapatkan skor?"

Dari pertanyaan tersebut didapatkan jawaban sebagai berikut: kalah duluan mengacungkan tangan, susah menyusun kalimat jawaban, Pandangan pemimpin presentasi tidak merata,anggota kelompok terlalu pendiam,takut jawabannya diserang disanggah,yang ditunjuk untuk menjawab itu-itu saja padahal sudah ngacung duluan, anggota kelompok terlalu lamban, kelompok tidak/kurang menguasai materi,anggota kelompok susah diajak aktif.
Pada individu yang belum aktif, Peneliti memberi pertanyaan sebagai berikut : "Mengapa kalian tidak berpartisipasi "?

Dari pertanyaan tersebut didapatkan jawaban sebagai berikut : Merasa asing dengan materi ini, banyak istilah yang tidak dimengerti, geli dengan masalah-masalah yang dibahas, malu mau bertanya tentang masalah yang dibahas, merasa kuper ketika membahas materi,kurang akrab dengan anggota kelompok yang lain sehingga kurang bisa terbuka kepada teman-teman, pendidikan sek itu tabu untuk dibahas, takut dinilai jelek oleh teman-teman,khawatir rahasianya terbuka,tidak sepantasnya materi ini dibahas di kelas,Gengsi, kalau jawabannya dianggap tidak berbobot, Dan sebagainya.

Peneliti merangkum hasil refleksi ini dan mempersiapkan untuk penampilan presentasi kelompok berikutnya pada tatap muka ketiga atau terakhir pada siklus pertama ini. Hasil rangkuman di komunikasikan kepada siswa untuk menjadi catatan pada pertemuan yang akan datang. 
Pada pertemuan ke tiga siklus pertama digunakan untuk presentasi 4 kelompok yaitu kelompok V,VI, VII, VIII. Pelaksanaan sama dengan pertemuan sebelumnya. Giliran pertama jatuh pada kelompok VIII dan secara berturut-turut adalah kelompok VI, V dan terakhir kelompok VII. Pada sesson ini peneliti dibantu oleh pengamat memandu jalannya diskusi dan presentasi. Pada tatapmuka ini yang mendapatkan skor tertinggi adalah kelompok VI dengan skor 425.

Pada akhir pertemuan ini refleksi hanya dilaksanakan lebih kurang tiga menit, karena penampilan presentasi cenderung mundur dari waktu yang telah ditentukan. Materi bahasan berkembang meluas sejalan dengan bertambahnya pengetahuan siswa. Dan pada penampilan masingmasing kelompok terdapat banyak kemajuan dibandingkan dengan sesson pertama, misalnya: Keaktifan anggota kelompok relatif merata, kekompakan kelompok cenderung meningkat, keberanian mengemukakan pendapat meningkat, arus kerjasama lebih stabil,pembagian tugas dalam kelompok lebih jelas, individu lebih bertanggungjawab dalam meyusun pertanyaan dan jawaban,pemberian skor oleh kelompok lebih obyektif, pertanyaan yang disusun lebih berbobot, dan sebagainya.

\section{b. Hasil belajar}

Hasil belajar pada siklus pertama diperoleh nilai dari dua bidang yaitu (1) Nilai presentasi dan (2) nilai tugas pembuatan soal kuis. Masing-masing tugas dinilai secara individu maupun kelompok. Rekaman nilai siswa digambarkan pada tabel dalam lampiran. Aspekaspek yang dinilai dalam presentasi adalahsebagai berikut: kekompakan, sistematika penyajian, partisipasi anggota,pemerataan tugas anggota,spontanitas menjawab pertanyaan, bobot jawaban dari pertanyaan yang dibuat, tanggungjawab dalam memandu kuis, tanggungjawab dalam kelompok baik sebagai anggota maupun sebagai ketua, keberanian mengutarakan pendapat, semangat bersaing antar teman kelompok, ketepatan waktu presentasi, antara pertanyaan dan jawaban yang dibuat, ketepatan waktu penyelesaian tugas, 
kesesuaian materi kuis, dan sebagainya.

\section{c. Refleksi}

Berdasarkan paparan proses pembelajaran dan hasil belajar yang diperoleh pada siklus I diketahui bahwa sebagian besar siswa perlu dimotivasi untuk berani mengutarakan pendapat dalam diskusi, menerima saran dari kelompok /oranglain, membangkitkaan spontanitas dan mengatur diskusi supaya terjadi komunikasi multi arah, presentasi adalah hasil diskusi kelompok secara intensif. Siswa perlu dorongan untuk aktif bekerja baik secara individual maupun kelompok. Perlu dibiasakan bekerja secara tim yang saling mendukung.

Hasil kerjasama yang ditampilkan oleh kelompok sangat bervariasi, hasil kerja individu juga sangat bervariasi, hal ini sangat di pengarui oleh beberapa faktor antara lain : situasi dan kondisi bulan puasa, keadaan siswa, kemampuan siswa, pemahaman siswa terhadap materi dan pemahaman siswa terhadap aspek komunikasi kelompok, serta kecocokan dan kekompakan kelompok.

dikatakan bahwa pembelajaran ini dapat membantu siswa untuk meningkatkan tanggungjawab dan kerjasama baik secara individu maupun kelompok.

\section{SIKLUS II}

Pada tahap ini yang disiapkan adalah silabus pembelajaran, yang dikembangkan melalui satuan layanan pembelajaran dan sekenario pembelajaran. Menyiapkan instrumen pengamatan yang berupa pedoman observasi dan log book (buku catatan pelaksanaan penelitian), instrumen penilaian skala sikap. Waktu yang diperlukan dalam siklus pertama 3 x tatap muka, masing-masing tatap muka $2 \times 45$ menit. Tatap muka I: diskusi, tatap muka ke II presentasi kuis tim, dan tatap muka ke III presentasi kuis tim dan pengisian angket. Tatap muka I ada 4 kelompok presentasi, masing,masing kelompok menggunakan waktu 20 menit, 10 menit terakhir untuk sharing.

Pada bulan Juli minggu keempat dibagikan modul materi pembelajaran kepada masing-masing 
kelompok, dari kelompok satu sampai kelompok delapan.

Pada pertemuan atau tatap muka pertama selama sembilan puluh menit siswa diberi kesempatan untuk berdiskusi menyusun pertanyaan kuis sekaligus membuat jawaban dari pertanyaan yang telah mereka buat secara kelompok. Masing-masing kelompok membuat pertanyaan kuis sesuai dengan jumlah anggota kelompok. Masingmasing anggota kelompok bertanggungjawab atas satu pertanyaan, jawaban, dan kemungkinan pengembangan diskusi atas pertanyaan tersebut. Peneliti bertindak sebagai fasilitator pada pertemuan tersebut, mendampingi,membimbing dan mengarahkan jalannya diskusi sampai selesai.

\section{b. Pelaksanaan Tindakan II}

Pada pertemuan pertama ini diambil kesepakatan bahwa pada tatap muka kedua ada 4 kelompok yang maju untuk presentasi kuis, dan 4 kelompok berikutnya maju presentasi pada tatap muka ke tiga. Setelah tatap muka ke tiga selesai akan diadakan refleksi dan pengisian angket untuk mendapatkan umpan balik pelaksana an pembelajaran aktif kuis tim.

Pada tatap muka kedua dilakukan presentasi kuis dengan cara mengadakan undian untuk menentukan kelompok mana yang akan maju pertama kalinya. Dari undian tersebut ternyata yang maju adalah kelompok VII. Masingmasing kelompok memiliki waktu 20 menit untuk menyajikan kuisnya. Dari penyajian kelompok VII ini yang mendapatkan nilai tertinggi secara berturut-turut adalah : Kelompok IV mendapat nilai 550, kelompok III 520, kelompok I 480, kelompok II 470, kelompok VIII 410, kelompok VI 405, kelompok V 390. Dengan demikian yang akan maju pada kuis kedua adalah kelompok IV sebagai pemimpin kuis. Penampilan kedua adalah kelompok IV, dan kelompok VII sebagai pendukung diskusi, jika mendapatkan nilai tertinggi tidak tampil kembali , tetapi penampilan diambilkan dari nilai tertinggi dibawahnya. Pada penampilan kedua ini secara berturut-turut adalah kelompok V 475, kelompok I 460,kelompok VII 440, KelompokVIII 435, kelompok VI 
425, kelompok II 400,kelompok III 390, dengan demikian yang maju pada babak kuis ke tiga adalah kelompok $\mathrm{V}$.

Pada penampilan kelompok $\mathrm{V}$, perolehan skor secara berturut turut adalah kelompok VIII 530, kelompok VI 505, kelompok I 495, kelompok III 475, Kelompok VII 455, kelompok IV 430, kelompok II 405 .

Penampilan ke empat jatuh pada kelompok VIII. Perolehan skor secara berturut turut yaitu kelompok III 465, kelompok II 450, kelompok VI 435, Kelompok IV 420, kelompok VII 400, kelompok V 360 , kelompok I 235.

Tatap muka ke dua telah berakhir, pada akhir pertemuan diberitahukan kepada seluruh siswa bahwa, kelompok yang mengumpulkan skor tertinggi akan mendapatkan reward. Penampilan kelompok selanjutnya akan diteruskan pada pertemuan atau tatapmuka ke tiga. Pada tatap muka ke tiga ini direncanakan menggunakan waktu 90 menit, dengan tahap-tahap sebagai berikut: presentasi kuis 80 menit untuk empat kelompok, masing-masing kelompok 20 menit,10 menit terakhir digunakan untuk refleksi terakhir dan mengisi angket umpan balik pelaksanaan kuis.

Presentasi pertama pada sesion ini adalah kelompok III, pada penampilan kelompok ini perolehan skor secara berturut- turut adalah: Kelompok II 470, kelompok III 425, kelompok VI 425, kelompok V 420, kelompok VIII 420, kelompok I 410. dan kelompok IV 400. Pada presentasi kali ini perolehan nilai ada persaingan cukup ketat dikarenakan siswa termotivasi untuk mendapatkan reward.

Penampilan selanjutnya adalah kelompok II. Pada presentasi kali ini secara berturut-turut perolehan nilainya adalah sebagai berikut: kelompok IV 470. kelompok VI 455, kelompok V 450, kelompok III 425, kelompokVII 425, kelompok I 410, kelompok VIII 405. Berhubung skor tertinggi diperoleh kelompok IV yang sudah presentasi maka kesempatan pada ranking bawahnya yaitu kelompok VI. Selanjutnya perolehan nilai pada presentasi kelompok VI sebagai berikut : kelompok III 450. kelompok IV 430, kelompok VII 
425. kelompok V 415, kelompok II

415. kelompok I 410, kelompok VIII 400.

Penampilan berikutnya

kelompok II, perolehan skor pada presentasi kelompok ini adalah kelompok III : 455, kelompok IV : 450, kelompok VII : 435, kelompok I

: 425 Kelompok VIII : 415, kelompok VI : 410, kelompok V : 400.

Penampilan terakhir adalah kelompok I. Pada presentasi kelompok ini relatif menggunakan waktu lebih cepat karena ada beberapa pertanyaan kuis yang sudah terjawab pada session sebelumnya. Dan pada presentasi terakhir cukup heboh karena masing-masing kelompok berebut memperoleh skor, sehingga pemberi pertanyaan merasa bingung kelompok mana yang tunjukjari lebih dulu untuk menjaab pertanyaan. Namun demikian bisa diatasi dengan cara pendampingan kelompok oleh pengamat yang membantu peneliti dalam pelaksanaan kuis tersebut. Perolehan nilai pada presentasi terakhir adalah sebagai berikut: Kelompok IV 460, kelompok III 450, kelompok VII 435, kelompok II 425, kelompok V
420, kelompok VI 405, kelompok VIII 390.

Presentasi kelompok telah selesai dilakukan, kegiatan berikutnya adalah refleksi kegiatan untuk siklus ke II dan dilanjutkan dengan pengisian angket umpan balik kegiatan. Untuk tatap muka ketiga atau terakhir waktunya mundur 15 menit, karena diskusi berkembang melebar.

\section{c. Observasi dan Pencatatan Data}

\section{Hasil Belajar}

Hasil belajar pada siklus kedua diperoleh nilai dari dua bidang yaitu (1) Nilai presentasi dan (2) nilai tugas pembuatan soal kuis .Masingmasing tugas dinilai secara individu maupun kelompok. Rekaman nilai siswa digambarkan pada tabel dalam lampiran. Aspek-aspek yang dinilai dalam presentasi adalahsebagai berikut: Kekompakan,sistematika penyajian, partisipasi anggota, pemerataan tugas anggota, spontanitas menjawab pertanyaan, bobot jawaban dari pertanyaan yang dibuat, tanggungjawab dalam memandu kuis, tanggungjawab dalam kelompok baik sebagai anggota maupun sebagai ketua,keberanian mengutarakan 
pendapat, semangat bersaing antar teman kelompok,ketepatan waktu presentasi.

Sedangkan aspek yang termasuk dalam penilaian tugas adalah: kesesuaian antara pertanyaan dan jawaban yang dibuat, ketepatan waktu penyelesaian tugas, kesesuaian materi kuis, dan sebagainya.

\section{c. Analisis dan Refleksi}

Pada siklus kedua, kualitas proses dan hasil belajar siswa menunjukan kecenderungan kearah lebih baik dibandingkan pada siklus pertama. Walaupun demikian masih perlu perbaikan dalam hal tanggungjawab dalam kelompok belajar. Aspek ini merupakan bagian yang sangat penting dalam proses pengembangan diri siswa, terutama pada penyelesaian tugas -tugas kelompok menjelang project work tugas akhir di kelas III .

\section{d. Upaya Perbaikan Untuk}

\section{Selanjutnya}

Pemantapan implementasi model pembelajaran aktif kuis tim perlu diadakan pada siklus berikutnya dengan cara merekam dengan vidio syuting, kemudian siswa mengamati rekaman tersebut bersama-sama. setelah mengamati ,membuat perbandingan antara sebelum diterapkannya pembelajaran kuis tim dan sesudah diterapkannya metode pembelajaran aktif kuis tim tersebut agar bisa melihat secara obyektif peningkatan tanggung jawab dalam kelompok belajar terhadap masing-masing individu. Mengamati secara bersama-sama akan membawa dampak positif terhadap pemahaman diri individu maupun pemahaman kelompok dalam rangka pengembangan diri masing-masing individu maupun kelompok. Refleksi semacam ini sangat diperlukan untuk membangun, menu $\mathrm{m}$ buhkembangkan rasa tanggungjawab siswa dalam kolaborasi kelompok belajar. Refleksi dengan pengamatan bersama akan lebih menyenangkan, karena siswa saling mengoreksi diri mereka masing-masing sambil membahas dengan peneliti sebagai guru pembimbing mereka.

\section{HASIL PENELITIAN}

Paparan pada proses pembelajaran dua siklus yang dilakukan tersebut menunjukan bahwa penggunaan pendekatan metode pembelajaran aktif kuis tim 
telah dapat meningkatkan tanggungjawab individu dalam kelompok belajar. Siswa dapat secara aktif berpartisipasi dalam merancang, merencanakan,menyiapkan melaksanakan ,menilai, mengevaluasi kegiatan pembelajaran dengan suasana yang lebih menyenangkan ( joyfull learning) . Keterlibatan secara langsung dan menyenangkan ini merupakan pengalaman kebermaknaan hidup dalam belajar, baik makna yang dirumuskan maupun makna yang dihayati (reference and sense of meaning).Siswa lebih termotivasi untuk berusaha secara bersama-sama dalam mengumpulkan informasi, berdiskusi, berlatih, berkonsulasi, presentasi dalam kelompok belajar. ( kooperative and kolaborative learning). Semangat bersaing secara sehat akan terbentuk melalui kegiatan kelompok belajar semacam ini.

\section{PENUTUP}

Berdasarkan hasil penelitian yang dipaparkan pada bab sebelumnya, maka dapat disimpulkan bahwa penggunaan model pembelajaran aktif kuis tim dapat meningkatkan tanggung jawab individu dalam kelompok belajar. Peningkatan tanggung jawab tersebut dapat diamati atau diketahui melalui partisipasi siswa dalam kelompok, keaktifan siswa dalam diskusi, keberanian mempertahankan pendapat, keberanian dalam presentasi, motivasi penyelesaian tugas yang tinggi, kemampuan bersaing, peningkatan rasa percaya diri siswa. Sedangkan indikator peningkatan tanggung jawab tersebut dapat dilihat dari makin meningkatnya kualitas penyelesaian tugas dan unjuk kerja siswa.

Berdasarkan hasil penelitian ini dapat disarankan bahwa model pembelajaran aktif kuis tim perlu dilaksanakan secara optimal pada mata pelajaran yang lain. Penggunaan pembelajaran model aktif ini dapat di gunakan untuk meningkatkan kualitas proses pembelajaran secara akademis. Pada umumnya dan proses pengembangan diri pada khususnya.

Penelitian ini perlu diteruskan agar ada kesinambungan peningkatan kegiatan (Continual Improvement) dalam kegiatan pembelajaran dan dalam peningkatan aspek 
kepribadian, pengembangan aspekaspek individu yang lain. 


\section{DAFTAR PUSTAKA}

Arikunto, S. 1998 Prosedur Penelitian Suatu Pendekatan Praktek. Jakarta, PT Rineka Cipta

Nur, M., Wikandari, Prima, R., Sugiarto. 1998. Pendekatan pendekatan Konstruktivis dalam Pembelajaran. Surabaya, IKIP Surabaya

Semiawan, C 1987, Pendekatan Keterampilan Proses Bagaimana Mengaktifkan Siswa Dalam Belajaran.Jakarta, PT Gramedia

Silberman L Manvil, 1996. Active Learning, Bandung PT. Nusa Media

Slavin,

$$
\text { R.E. }
$$
1986. LearningTogether, VII/002. Summer 1986 1-7 Amerika,

American Educator.

Sott, Cherie Carter, 2004. Trust Your Life, alih bahasa Fistaulina FS. Jogyakarta PT Inspirasi Buku Utama.

Tim Peneliti Proyek PGSM, 1999 Penelitian Tindakan Kelas. Jakarta, Departemen Pendidikan dan Kebudayaan

Winkel, W.S. 1999, Psikologi Pengajaran (Edisi Revisi), Jakarta, Grasindo 